\title{
Transposition
}

Musique et Sciences Sociales

Hors-série 2 | 2020

Sound, Music and Violence

\section{From Music to Armed Struggle, from 1968 to Action Directe: An Interview with Jean-Marc Rouillan}

De la musique à la lutte armée, de 1968 à Action directe : entretien avec JeanMarc Rouillan

Luis Velasco-Pufleau

\section{OpenEdition}

\section{Journals}

Electronic version

URL: http://journals.openedition.org/transposition/3780

DOI: 10.4000/transposition.3780

ISSN: $2110-6134$

Publisher

CRAL - Centre de recherche sur les arts et le langage

\section{Electronic reference}

Luis Velasco-Pufleau, «From Music to Armed Struggle, from 1968 to Action Directe: An Interview with Jean-Marc Rouillan », Transposition [Online], Hors-série 2 | 2020, Online since 15 March 2020, connection on 15 April 2020. URL : http://journals.openedition.org/transposition/3780 ; DOI : https:// doi.org/10.4000/transposition.3780

This text was automatically generated on 15 April 2020

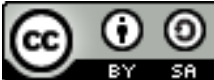

La revue Transposition est mise à disposition selon les termes de la Licence Creative Commons Attribution - Partage dans les Mêmes Conditions 4.0 International. 


\title{
From Music to Armed Struggle, from 1968 to Action Directe: An Interview with Jean-Marc Rouillan
}

De la musique à la lutte armée, de 1968 à Action directe : entretien avec JeanMarc Rouillan

\author{
Luis Velasco-Pufleau
}

\section{AUTHOR'S NOTE}

The following is from an interview at the Maison des métallos in Paris on 10 April 2019. This meeting was part of the research I have been conducting for several years on the role of sound and music in dynamics of violence and armed struggles. In this context, the testimony of Jean-Marc Rouillan seemed to me to be of undeniable importance. The text retains, as far as possible, the general tone of the meeting. I would like to thank Rémi Philton and Stéphanie Gernet for making this interview possible, and Thierry Discepolo for his contributions to the editing of this text.

\section{Introduction}

1 Jean-Marc Rouillan was born in Auch (France) in 1952. He participated in the antiFranco struggle and the autonomist movements in Spain and France in the late 1960s and early 1970s. He then continued in armed struggle with Action directe (1977-1987). Described as an extreme left-wing terrorist group by the French State and the media, the members of Action directe considered themselves to be a European revolutionary group-like the Red Army Fraction (Rote Armee Fraktion, RAF) in Germany and the Red Brigades (Brigate Rosse, BR) in Italy. For Action directe, the struggle for emancipation and autonomy was indissociable from "challenging the monopoly of violence held by the State". ${ }^{1}$ Consequently, armed struggle was part of their existence, including bank 
robberies, machine-gun fire and bomb attacks against state buildings or international military organisations (NATO, Interpol), followed by targeted assassinations of industrial and military leaders.

In February 1987, Jean-Marc Rouillan was arrested with the other members of the historic nucleus of Action directe, and sentenced to life imprisonment. He spent 28 years in prison, including roughly ten years in solitary confinement. He was granted various parole arrangements between 2007 and 2018. Since his final release on 18 May 2018, he can now express himself publicly about the actions for which he was convicted. In this interview, Jean-Marc Rouillan talks about the connection between his musical practice and his political commitment since the May 1968 events in France, the role of music and sound in the armed struggle of Action directe, and the place he attributes to music in the history of political struggles.

\section{Music and politics: from 1968 to Action directe}

LUIS VELASCO-PUFLEAU: In your book Je regrette, you say that at one time you played guitar and electric bass. ${ }^{2}$ What role did music play in your political activism and in your choice to use armed violence?

Jean-Marc Rouillan: We should go back to the beginning of my activism, because my political commitment in 1968 was preceded by musical commitment. The music, literature, poetry and underground culture of the 1960 s were central to my commitment. Playing music was like going underground in anticipation of something, in anticipation of a confrontation. But that could not satisfy the commitment that my life was going to make. Finally, the May 1968 events in France arrived and I moved from music to political activism - it is complex and cannot be untied. Then, the armed activism drew its inspiration from the same culture as the punk and autonomist movements. For me and the other members of Action directe, music, literature, poetry-the arts-were crucial to our armed action.

\section{LVP: How did your listening to music give meaning to the upcoming confrontation?}

JMR: When I was a kid, listening to a particular song was a shock. I was listening to the song "Gloria" by Them, an Irish band from the 1960s, on the jukebox. After the guitar solo of this song, there is a reprise where you really feel that something is going to happen, that something has to happen. When I was listening to this music, I said to myself, "Something will happen in our lives". The English musical wave preceded 1968; it shaped it culturally but preceded it in expression: "We are the baby boom generation and we won't accept to be ordered about by the old and always wear grey". This idea was expressed by the music. Speaking of a love story, Them would say, "We're going to shake up the world".

LVP: Then 1968 brought about the changes you were waiting for.

JMR: Music was part of this expectation of the spread of the conflict, in which I was going to play my part. Before the first demonstration I went to in May 1968, we were waiting to go to rehearsal in a bar, listening to the jukebox. A friend came into the bar and said, "What? You're going to rehearse when there's a demonstration? We're going to go fight the cops." And we said, "Okay, let's go fight." After May 1968, militant activism meant that I could no longer play music. It was a choice. 
LVP: So you "put away your Fender guitar" and abandoned your "plan to move to a music squat near Piccadilly Circus". ${ }^{3}$ Did you completely stop playing music after 1968 ?

JMR: I hardly played any more, except in the hideouts in Spain in the early 1970s, when I was involved in the armed struggle against the Franco dictatorship. Most of the Catalan Spanish comrades had had a musical life before their life in hiding. There were always guitars, and people played them at night. Sometimes, during the day, we would play a few chords together; we would sing. I had a culture of protest songs: anti-Franco through Paco Ibañez and Latin American with Quilapayun. At that time, we listened to a lot of music.

LVP: What was the music you were listening to at the time of Action directe?

JMR: The music we were listening to at the beginning of Action directe, at our meetings or on our car radios in 1977-1978, was mainly punk and a little rockabilly. We also listened to singers, like Léo Ferré, whose lyrics were close to our militant commitment. But above all we listened to punk: The Clash, much more than the Sex Pistols. There was a politicization that spoke to us, the punk culture of "Do it yourself -DIY" was decisive for us.

LVP: Did you often go to concerts together?

JMR: Yes, at that time we were doing armed actions but were not really "wanted" yet, so we could go to shows. One such musical adventure of the historic nucleus of Action directe is when we went to London in July 1977 for a major rockabilly festival. We saw Crazy Cavan and other old rockabilly bands. Then in the evening we went to the Marquee Club, where we saw a concert of the Pirates, Johnny Kidd's former band. The following year, we saw The Clash in concert in Paris. ${ }^{4}$

LVP: How important was this show for you?

JMR: It was important because it was at the time of the autonomous movement. In 1978, we kept the spirit of freemusic, this late-1960s principle of not paying for concerts when they were organised by big companies that made money with music. When we went to see The Clash, there were about three hundred of us autonomous activists, and we said we were going to force our way in. That's when Joe Strummer came out and asked what was going on. ${ }^{5}$ We explained the situation to him, that we were not going to pay to come in and see them. He said, "Okay, as soon as we start the first song, they'll open the doors and you can come in". It was the first time I met Joe Strummer. The second time was in 1981 (at the beginning of the Mitterrand years, when Action directe was legal); he was in Paris doing a concert at the Mogador theatre and we met for a coffee.

\section{Resisting the commodification of music}

LVP: This incident resonates with another episode in your book Je regrette, in which you talk about wanting to "free the music from the merchants", at the Isle of Wight Festival in 1970. ${ }^{6}$

JMR: Our generation of activists was used to groups being born in pubs or small concert halls. We would have a beer and listen to music; there was a whole atmosphere. Then came this trend of big concerts, initially free, but we soon found ourselves behind big investors who made money with that. There were the first editions of the Isle of Wight Festival, but I didn't go, given the price of the tickets and the concentration camp atmosphere of the music: they held the festival in the 
countryside but were putting up high walls to protect their business. In 1970, there was a call from activists to go to the Isle of Wight and force the organizers to make the festival free. We went over and for two weeks fought every night with the cops, with Hells Angels and with the private security agents trying to protect the thing. We kept fighting until the festival was free. Free music was a political struggle; we understood it as such.

LVP: You refused the commodification of music while supporting musicians themselves.

JMR: Musicians have to be able to make a living from their music, which is why we paid like everyone else when it came to small concerts, when we knew the money went to the musicians. But at Wight or Woodstock, they were big companies that were set up to make so-called free, peace and love festivals. But it was to make money. It wasn't easy to fight against commodification, the monopoly of these big companies who understood that they could make a lot of money with rock-when it was our music, the music of the pubs, the music of the small concerts, the music of our meetings. This struggle lasted from the 1970 s to the punk era. There was a divergence there. On one hand there was the music listened to in big venues, like at La Villette. Music imprisoned, protected by the police. On the other hand there was punk, with the Do It Yourself spirit. People were saying, "I can play punk, too. So we are going to make our own music again, because this is no longer ours. It has been taken over". The spirit of free music was to find a common space with musicians, like in British pubs in the early 1960 s.

LVP: Making music yourself was an act of emancipation?

JMR: Yes, emancipation of people, and also of music. Because sometimes bands have pushed the boundaries of music itself. With their shouting, for example, it was more an expression of rage than the music from soul or blues that we were used to hearing.

LVP: What was the music you didn't listen to, the music you couldn't stand?

JMR: We had a word for it: "soup". We couldn't stand this music, which is no more than a commodity. For example, I listened to the Rolling Stones until 1972-1973. After that, it was just "soup". They did disco and other things to make money. When music becomes only about making money, there is no longer any political message. Not only in the lyrics, but also in the sound.

LVP: Were there any other British bands you couldn't stand?

JMR: Bands like Cream, in which Eric Clapton played. Clapton is someone I've never liked, even when he was with the Yardbirds. Clapton was one of the people who stank of "I want to make money; I play guitar to make money". He was not someone who played a role in struggles; moreover, later on, he was a sympathizer of the ideas of the National Front and all that fascist bullshit. Kind of like David Bowie: he made great songs, but it smelled too much like money. It did not fit with the militant commitment of our generation.

LVP: In terms of your anti-imperialist ideology, did you associate certain groups with US imperialism?

JMR: I think that from the moment bands sold their music to big managers, their music somehow "imperialised" our culture. Even bands like The Velvet Underground; it smelled too much like fake underground. The bands I followed were bands I saw in pubs or small gigs. 


\section{Music and armed struggle}

LVP: At the time of Action directe, did you listen to music before your armed actions?

JMR: No, didn't listen to music. We were extremely focused on the action; there was also fear. Music came after, when a highly stressful moment had passed, to relax or lower our adrenaline. It was the beginning of the Walkman. So there were activists who, after armed actions, put music in their Walkmans. But it wasn't necessarily the music we listened to the rest of the day. At that time, we listened to Pink Floyd or other things that were more "zen". Sometimes we also listened to classical music, Mozart or Fauré, for example.

LVP: This listening was more solitary listening.

JMR: Yes, when someone needed music to wind down, they would take a drink and their Walkman, sitting in an armchair.

LVP: Did you sing after your armed actions?

JMR: Not really, but it could happen. Recently I went to Rome and an Italian comrade told me, "Remember when, after an action, we sang a ridiculous Italian pop song, 'Sarà Perché Ti Amo'...". Yes, I remembered that we sung it at the top of our lungs in the car, just for fun.

LVP: In the evenings, were there also moments of collective listening?

JMR: Yes, of course, but it didn't have the same function. As the flats were often shared and the instruction for underground members was not to go out after 9 p.m., in the evening we all took turns playing our 33 vinyls. The repertoire was more varied: old records from the 1960s, punk or rock. Since we didn't watch television, we used our time for music or writing. Music was a daily presence.

LVP: Another characteristic of your armed struggle is its internationalist dimension, which took the form of exchanges and joint actions with other armed groups in Europe (RAF [Rote Armee Fraktion], Red Brigades [Brigate Rosse]) or the Middle East (PLO, Kurds). Did you share music among activists when you were in another country or when there were foreign activists passing through your home?

JMR: Generally, we listened to the music that the activists listened to wherever we were. But even if musical exchanges were not central to our activities, they had an influence on our musical spheres. In the early 1970s in Spain, I introduced Catalan comrades to English music, not what they heard on their radios, but garage music, the first albums of T. Rex, for example. Towards the end of Action directe, German RAF activists were listening to a lot of industrial music, much more than punk. Thanks to them, I discovered new music that I started listening to regularly. We were trying to share what we loved.

LVP: What emotions do you associate with the music shared at that time with your comrades?

JMR: Those early years of the armed struggle, in the early 1970s, were very hard. Many comrades died during that period. But at the same time, those years are characterized by immense joy, immense camaraderie between people. My memories of music remind me that there was a lot of joy during those times, with the Italians, with the Germans, with all those people who had come to fight in Paris. 


\section{Sound and revolutionary tactics}

LVP: In your latest book Dix ans d'Action directe, you devote several pages to your surveillance listening to police radio and tracking the frequencies of special units. You say that your "methods of cross-checking and the work of surveillance listening" have often given you "a slight step ahead repression." Could you say a little more about the role that surveillance listening played in your armed struggle?

JMR: Information has always had a crucial role to play in the struggle. Monitoring the adversary was a necessity to win the battle. They were watching us and we were watching them. Action directe, as a guerrilla war, was therefore forced to create a function of countersurveillance of police actions. Thanks to radio scanners (often made in the United States but purchased in Switzerland), we were able to intercept all communications-even the most local-from the repressive state apparatus. Until they found our surveillance notebooks, after many years, they had no idea of our capabilities. Many arrests were thwarted, which they thought was because of moles in their own departments or complicity in the state security services.

LVP: In the end, you hijacked one of the most common means used by states for surveillance purposes: the interception of communications.

JMR: Totally. We even intercepted the communications of counterintelligence services, the $\mathrm{DST}^{8}$ and the special units that were responsible for intercepting our communications.

LVP: How did the sound of radio (police or pirate radio) shape your daily life?

JMR: Most of the time, surveillance devices were in use in the apartments and commando cars. The sounds of these communications were part of our daily lives, or sometimes one of us used headphones. The devices were scanning the police's main communication radio waves. Before operations, we checked that there were no special unit members in the area.

For pirate radio stations, too, it was a question of obtaining information. We followed the movement's debate shows. People knew we were listening and often they would speak to us directly, to criticize and make suggestions. All of this was a live and constant sound that punctuated our militant lives, like the sound of Paris, the frenetic city-our own sierra...

\section{Music and the collective memory of political struggles}

\section{LVP: For you, can music be a political collective memory, a way of not forgetting the political struggles of the past?}

JMR: Collective memory is a struggle for both music and political acts themselves. If we leave the collective memory of our political struggle in the hands of those who won the battle, there is no longer any collective memory, only their version of the facts. When it comes to music, if we don't go deep into the music of those years, it will always boil down to "soup". I think our generation integrated the music it has listened to and produced, as a political act. This is rarely the case today. I think we have to keep at it: it's important to explain this to the new generations. We have to fight to reclaim the collective memory of our music. 
LVP: In what way is collective memory a condition for political struggles?

JMR: Collective memory is part of any revolutionary struggle. There is not one revolutionary struggle that was born spontaneously (as was thought of some $19^{\text {th }}$ century diseases). Collective memory is a breeding ground for struggles: if you know the past of the revolutionary movement, you find strength, experience and a lot of other things. There is no struggle without knowledge of the past: if we lose our collective memory, we lose the meaning of our struggle.

LVP: In what way is music part of this collective memory?

JMR: Music has a political history. There are young people who listen to music without knowing where it comes from. They think it comes from recent political movements. But if you know music history from the 1960s to the present, you understand that some music comes from other movements or has links to older political struggles. For example, there is a political history behind ska. It emerged in clubs in London, where only West Indians and Irish people were accepted, and they were denied access to clubs reserved for English people. So they created their own music. That's why The Clash also had a penchant for other kinds of music, like reggae: Joe Strummer often went to these relegated clubs, where the first skins [skinhead movement] were located. All of this is nothing new and requires political articulation and understanding. Music is a constant fight under the influence of political struggles.

LVP: Do you think that the depoliticisation of music goes hand in hand with the depoliticisation of the collective memory of these struggles?

JMR: "Soup" that is produced reproduces commercial products. There's nothing left, only emotion. It's like a painter who just decorates your living room, who doesn't express anything fundamental. There are bands that always make bland, colourless music, for elevators: empty music. When you listen to music, your feelings have to have a quality of reflection on the world.

LVP: Is this reflection on the world driven by the lyrics or by the way music is played and interpreted?

JMR: Both, even if sometimes it may seem contradictory. For example, the lyrics of the British bands you could see in pubs in the 1960s, like Them, Small Faces, even The Who, talk about love stories and small stuff. But in their music, we feel the confrontation, we feel the rage, we feel that they refuse the world as it is. They will shout in the middle of the solo... The expression of this refusal is angry even if they're singing "I've got a date with my girlfriend in two hours". It's the music that speaks, not the lyrics. In creating their own take on soul music, The Animals or Small Faces added a spark of rage. They also added class content and the hope for something to change.

\section{Pushing the limits of what is possible}

LVP: For you, this music pushed the limits of what was possible.

JMR: Yes, absolutely. In the 1960s, we felt that there was still a barrier; but it was getting smaller and smaller. It finally exploded with Jimi Hendrix. From that point, we could do whatever we wanted. Musically, he did what he wanted because he was capable of doing it. In the same way, as a political movement, we were fed up with 
political parties and unions. So we said to ourselves, "We're going to do things differently".

LVP: How did this translate in your experience?

JMR: As soon as we got into a radical struggle against a deadly system, we tasted the fresh air of freedom and it was incredible. All we had to do was to enter into a radical conflict to be bigger, physically taller even, to straighten up. We said to ourselves, "All this is over; this world is over. I no longer want any part in it, because any participation in this world is fatal".

LVP: For you, Jimi Hendrix embodied this breakaway?

JMR: There are forerunners to Jimi Hendrix. But with him, from the beginning in 1966, we felt that the door was open. What was not possible four years before, Jimi Hendrix said, "It's possible now. We have decided that it's possible". It was a decision. And Jimi Hendrix would say "I'm free" in a seven- or eight-minute solo. Then, right away, people showed up to sell this freedom-major labels and concert managers. They played with this feeling of freedom, in order to sell it to our entire generation. They turned it into commercial products. We spent two or three years buying it, and then we thought, "No, we're getting fucked".

LVP: Until other musicians also refused to submit to the market.

JMR: Punks represented this renewal, the new spark in music around 1976-1977. They said, "We're not going to fall into this 'soup' music trap. We're going to make music ourselves, at home". They wanted to tell us that anyone could be a member of the Sex Pistols. Everywhere, people and groups emerged, who wanted to make music without being great musicians. It was a new kind of freedom-even though, later, the market usurped this freedom too.

LVP: It's a constant battle to avoid being turned into something else...

JMR: That's true, as much for music as for Action directe. As long as some of us can talk, we can't be controlled. We refused to sell out. And as long as we can thwart a political distortion, it is impossible to cross the divide that we dug between them and us. They can always present us as fools (or worse), try to make what we did sound like very little, mock our action. But as long as we are alive and able to provide our own account, being turned into something else will be very difficult.

\section{BIBLIOGRAPHY}

ROUILLAN Jann Marc, Je regrette, Marseille, Agone, 2016.

https://agone.org/jeregrette/

RoUILLAN Jann Marc, Dix ans d'Action directe : Un témoignage, 1977-1987, Marseille, Agone, 2018.

https://agone.org/dixansdactiondirecte/ 


\section{NOTES}

1. Rouillan Jann Marc, Dix ans d'Action directe: Un témoignage, 1977-1987, Marseille, Agone, 2018, p. 36.

2. ROUILLAN Jann Marc, Je regrette, Marseille, Agone, 2016, chaps. 33 and 173.

3. Ibid., chap. 33.

4. [Editor's note] The Clash gig took place on 16 October 1978 at the Stadium, 66 avenue d'Ivry in Paris.

5. [Editor's note] Joe Strummer (1952-2002) was the singer and guitarist of The Clash.

6. ROUILLAN, Je regrette, chaps. 175-176.

7. ROUILLAN, Dix ans d'Action directe, pp. 220-221.

8. The Direction de surveillance du territoire (DST) was responsible for counterespionage and counterterrorism-the French equivalent of the FBI in the United States and the British MI5. Created in 1944, it was merged in 2008 with the Direction centrale des renseignements généraux (often called

Renseignements Généraux, RG) into the new Direction générale de la Sécurité intérieure (DGSI).

\section{ABSTRACTS}

Jean-Marc Rouillan is one of the founding members of Action directe (1977-1987). In this interview, he talks about the connection between his musical practices and his political activism since the May 1968 events in France, the role of music and sound in the armed struggle of Action directe, and the place he attributes to music in the history of political struggles.

Jean-Marc Rouillan est l'un des membres fondateurs d'Action directe (1977-1987). Dans cet entretien, il parle des liens entre sa pratique musicale et l'expérience sensible de son engagement politique depuis 1968, du rôle de la musique et du son dans la lutte armée d'Action directe, ainsi que de la place qu'il attribue à la musique dans la mémoire des luttes politiques.

\section{INDEX}

Keywords: Action directe, armed struggle, terrorism, music, politics, DIY, Rote Armee Fraktion, Clash, Hendrix (Jimi), punk rock

Mots-clés: Action directe, lutte armée, terrorisme, musique, politique, DIY, Rote Armee Fraktion, Clash, Hendrix (Jimi), punk rock

\section{AUTHOR}

\section{LUIS VELASCO-PUFLEAU}

Luis Velasco-Pufleau is a musicologist and sound artist. He is currently a SNSF researcher at the University of Bern (Walter Benjamin Kolleg / Institute of Musicology). His work critically reflects on the relationship between music and politics in contemporary societies. As a researcher and sound artist, he is interested in exploring innovative forms of writing at the crossroads of artistic creation and research in the humanities and social sciences.

ORCID: https://orcid.org/0000-0002-1330-974X 